\title{
STRATEGI PEMASARAN DALAM MENINGKATAN USAHA PARA ANGGOTA BAITUL MAAL WAT TANWIL
}

\author{
Karebet Gunawan \\ Prodi. Ekonomi Syariah, STAIN Kudus \\ betaguna@gmail.com
}

\section{Abstrak}

Ada berbagai faktor yang menentukan kesuksesan sebagai wirausaha diantaranya modal usaha, pasar, kondisi persaingan, dan trend bisnis. Oleh karena itu, secara teori tidak cukup hanya mengandalkan insting dalam mengambil keputusan di dunia bisnis tetapi juga faktor yang lain. Lebih dari itu, diperlukan suatu kalkulasi yang komprehensif baik secara kualitatif maupun kuantitatif dari segala aspek yang berkaitan dengan usaha yang akan dibuat. orang yang berusaha atau berwiraswasta agar dapat lebih bersaing dan memiliki prospek perkembangan yang bagus, maka sebelum mendirikan orang yang berusaha atau berwiraswasta sebaiknya dilakukan manajemen pemasaran usaha terlebih dahulu.

Dalam penelitian kali ini, penulis menggunakan jenis penelitian field Reseach (Penelitian lapangan) yaitu penelitian yang mengambil data primer dari lapangan atau lokasi penelitian tertentu. Jadi 
dalam hal ini penelitian yang penulis lakukan berdasarkan pada data-data lapangan dan literatur yang berkaitan pada pokok persoalan yang dibahas. Dalam hal ini peneliti ingin meneliti tentang strategi pemasaran yang baik.

Permintaan yang didukung oleh kekuatan tenaga beli disebut permintaan efektif, sedangkan permintaan yang didasarkan pada kebutuhan saja disebut sebagai permintaan potensial. Strengths yang ada dalam pemasaran harus dipertahankan misalnya sudah punya nama yang baik dan sudah tahu bagaimana cara meraih konsumen maka harus dipertahankan. Weakness adalah mempunyai arti kelemahan yang ada lemah dalam pengendalian keuangan yang dilakukan oleh beberapa usaha misalnya masalah keuangan dimana jarang melakukan pencatatan walaupun dalam pembuatan nota. Sampai di mana penjual ingin menawarkan barangnya pada berbagai tingkat harga ditentukan oleh berbagai faktor.

Kata kunci :, Strengths, Weaknesses, Permintaan dan Penawaran.

\section{Abstract}

There are many factors that determine the successful of business, such as capital, market, competitive environment, and business trends. Therefore, it is not just enough to rely on instinct only in decisions making process, but also consider other business successful factors. Moreover, a comprehensive calculation is required both qualitatively and quantitatively from all aspects related to the business to be made. The aim of this study is to explore the effect of marketing strategy increasing business profit owned by BMT members. In this study, the author use the type of field research Reseach (field research) is research that takes primary data from the field or specific research sites. So in this case the research that the authors do based on field data and related literature on the subject matter discussed. 
In this case researchers want to research about a good marketing strategy.

Demand supported by the power of purchasing power is called effective demand, whereas demand based on demand alone is called a potential demand. Strengths that exist in marketing must be maintained for example already have a good name and already know how to reach consumers then must be maintained. Weakness is the weakness that exists is weak in the financial control performed by several businesses such as financial problems where rarely do the recording even in the manufacture of notes. Up to where the seller wants to offer his goods at various price levels is determined by various factors.

Keywords:, strengths, weaknesses, demand and supply. 


\section{PENDAHULUAN}

Kebutuhan akan modal menjadi tantangan bagi para wirausahawan.

Keinginan untuk selalu mengembangkan usaha dengan inovasi maupun ekspansi usaha menjadi kebutuhan wirausahawan sehingga kebutuhan modal menjadi hal yang krusial. Sekarang ini orang yang berusaha atau berwiraswasta tidak lepas dari usaha pemilik usaha untuk memenuhi kebutuhan terutama kebutuhan dana di mana dana tersebut diantaranya diperoleh dari BMT (Baitul Maal wat Tamwil). Pola fikir (mindset) pelaku usaha kecil dan usaha menengah adalah selalu ada keuntungan selama usaha masih dapat berjalan serta sangat mengandalkan insting bisnis dalam menjalankan usaha. Terdapat banyak faktor yang menentukan usaha dapat sukses atau tidak, diantaranya adalah modal usaha, pasar, kondisi persaingan, dan trend bisnis. Oleh karena itu, secara teori tidak cukup hanya mengandalkan insting dalam mengambil keputusan di dunia bisnis tetapi juga faktor yang lain. Lebih dari itu, diperlukan suatu kalkulasi yang komprehensif baik secara kualitatif maupun kuantitatif dari segala aspek yang berkaitan dengan usaha yang akan dibuat. orang yang berusaha atau berwiraswasta agar dapat lebih bersaing dan memiliki prospek perkembangan yang bagus, maka sebelum mendirikan orang yang berusaha atau berwiraswasta sebaiknya dilakukan

pemasaran usaha terlebih dahulu. Hal ini berguna untuk memperhitungkan kemungkinan apakah usaha dapat bersaing dan bertahan diantara para kompetitornya sekaligus melihat kemungkinan pengembangan usaha di masa depan yang dilihat dari berbagai aspek atau sudut pandang. Strategi adalah sejumlah keputusan dan aksi yang ditujukan untuk mencapai tujuan atau goal dan menyesuaikan sumber daya yang dimiliki dengan peluanpeluang yang dihadapi. (Mudrajad, 2005 : 12)

$$
\text { Suatu masyarakat, }
$$

usaha merupakan bagian penting sebagai tempat terjadinya interaksi dan komunikasi antar manusia dalam sebuah lingkungan masyarakat dan dapat meningkatkan taraf hidup masyarakat. Di dalam suatu usaha biasanya akan tercipta suatu kerjasama yang erat antar wiraswastawan dengan lembaga keuangan karena mereka merasa senasib Dalam sebuah kota, aktivitas usaha 
berperan sebagai wadah aktivitas perekonomian masyarakat yaitu sebagai tempat terjadinya transaksi jual beli antara konsumen dan pembeli.

Berdasarkan kondisi kultur budaya masyarakat pengguna yang masih mengedepankan unsur budaya tradisional dan mengingat belum pernah ada sebuah usaha yang bisa berkembang sangat pesat dengan modal yang sedikit sehingga perlu adanya tindakan evaluasi mengenai kondisi dan kualitas usaha yang telah diberikan untuk mempertahankan keberadaan usaha tersebut.

\section{Ruang}

lingkup pemasaran meliputi $4 \mathrm{P}$ yaitu produk, harga, promosi dan distribusi. Strategi produk yaitu tentang : kemasan (merk, mutu, manfaat, badan hukum), label (siapa yang membuat, kapan, cara pakai, isinya), jasa, asesoris. Lebih menitikberatkan pada karakteristik produk, alasan pembelian produk, kualitas produk, pengguna produk, pemisahan kelas produk. Strategi harga dipengaruhi oleh faktor internal yaitu disesuaikan

biaya produksi, sasaran perusahaan,faktor external yaitudisesuaikandenganharga dan tawaran produk pesaing, inflasi, ciri sang pembeli, kondisi ekonomi negara. Perlu diingat yang sering menjadi pertimbangan utama bagi para calon konsumen adalah tingkat harga, potongan harga. Strategi distribusi yaitu tentang jenis saluran, pengangkutan, penyimpanan dan tingkat pelayanan.Strategi promosi yaitu tentang periklanan, promosi penjualan, hubungan masyarakat dan penjualan perorangan. Sebaiknya lakukanlah promosi secara terus menerus jangan pada waktu pembukaan saja ingat kalau ingin mendapatkan ikan yang besar umpannya harus besar pula. Promosi memang perlu agar konsumen mengenal dan mengerti produk yang dihasilkan perusahaan.

Prosedurperamalandan permintaan yang dilakukan dalam melakukan pemasaran meliputi , analisa ekonomi yaitu dengan memperhatikan terhadap aspek-aspek makro terutama kependudukan dan pendapatan, analisa industri yaitu menganalisa terhadap seluruh perusahaan yang menghasilkan produk sejenis/ fungsi sejenis, analisa penjualan masa lalu.

Penelitian

akan diarahkan untuk mengkaji bagaimana sebenarnya manajemen pemasaran yang baik sehingga usaha yang dijalankan akan semakin maju. Kontribusi penelitian ini dalam 
dunia ilmu pengetahuan sebagai bahan evaluasi dalan pengembangan usaha kalangan menengah kebawah yang saat ini kondisinya semakin terpinggirkan oleh keberadaan usaha dengan modal yang besar.

\section{KAJIAN LITERATUR}

\section{A. Pemasaran}

$\mathrm{P}$ e $\mathrm{m}$ a $\mathrm{s}$ a $\mathrm{r}$ a $\mathrm{n}$ merupakan salah satu bagian pokok yang harus dilakukan oleh perusahaan untuk mempertahankan kelangsungan hidupnya, untuk berkembang dan memperoleh laba. Pemasaran berbeda dengan penjualan, perdagangan,

maupun distribusi, yang sebenarnya merupakan suatu bagian dari kegiatan pemasaran secara keseluruhan. Kegiatan pemasaran perusahaan harus memberikan kepuasan kepada konsumen jika perusahaan menginginkan usahanya berjalan terus dan berharap mempunyai pandangan yang baik terhadap perusahaan.

Indonesia memiliki jumlah penduduk terbesar nomor empat di dunia, setelah Negara-negara China, India dan Amerika Serikat. Menurut Bappenas jumlah penduduk Indonesia diperkirakan sebesar 118,3 juta jiwa pada tahun 1971, meningkat menjadi 146,7 juta jiwa pada tahun 1980, kemudian bertambah menjadi 179,2 juta jiwa pada tahun 1990 , dan menjadi sebesar 205,1 juta jiwa pada tahun 2000. Pada tahun 2000 jumlah penduduk Indonesia berjumlah 233,5 juta. Setiap hari penduduk yang terdiri dari laki-laki dan perempuan, usia anak sampai dengan usia lanjut, miskin dan kaya, kulit hitam, sawo matang dan kuning memerlukan pangan, sandang dan papan. Di samping kebutuhan, setiap penduduk juga punya keinginan, seperti ingin makan nasi, ingin makan jagung, ingin makan burger, ingin minum teh, ingin pakaian musim dingin, ingin pakaian musim panas, ingin rumah sederhana, ingin rumah susun, ingin rumah yang menginjak tanah, ingin rumah yang jauh dari tanah dan sebagainya. Penduduk juga membutuhkan pendidikan, kesehatan, ketenangan, kedamaian, dan kebutuhan hidup lainnya. (Mulyadi, 2013 : 23)

Pemasaran adalah suatu sistem total dari kegiatan bisnis yang dirancang untuk merencanakan, menentukan harga, mempromosikan dan mendistribusikan barang dan jasa yang dapat memuaskan kebutuhan baik kepada pembeli yang ada maupun pembeli potensial. Menurut Kotler pemasaran adalah 
proses sosial dan manajerial dengan nama seseorang atau kelompok memperoleh apa yang mereka butuhkan dan inginkan melalui penciptaan dan pertukaran produk dan nilai. Sedangkan menurut The American Association memberi Definisi pemasaran adalah suatu kegiatan usaha yang mengarahkan aliran barang dan jasa dari produsen kepada konsumen atau pemakai.

Dari beberapa Definisi di atas, dapat diambil kesimpulan bahwa pada prinsipnya mencakup pemasaran perusahaan yang dimiliki dengan mengidentifikasikan kebutuhan konsumen atau klien yang perlu dipuaskan, menentukan produk yang akan diproduksi, menentukan harga pokok yang sesuai, menentukan cara promosi dan distribusi dari produsen ke pelanggan. Kegiatan dibidang pemasaran yang dilakukan dalam menjalankan bisnis, dimaksudkan untuk dapat mengejar terjadinya transaksi yang

\section{transaksi} menguntungkan, dilakukan dengan pembeli atau pelanggan. Dalam melakukan juga perlu yang namanya komunikasi ada unsur Who (siapa), Says What (apa yang dikatakan) dan unsur Which
Channel meliputi media atau saluran. (Suharsono, 2013 : 10) Untuk memenuhi kebutuhan dan keinginannya, setiap penduduk harus membeli, kemudian menggunakan, memakai dan mengkonsumsi berbagai kebutuhan barang danjasa baik untuk memenuhi kebutuhan yang paling dasar sampai dengan kebutuhan untuk mengaktualisasikan dirinya. Selain membeli, penduduk bias juga membuat sendiri barang atau jasa yang dibutuhkan dan dinginkannya, kalau seluruh bahan baku dan bahan pembantunya mencukupi. Namun penduduk sering berfikir tentang mana yang lebih baik, membuat sendiri atau membeli dari orang lain. Dengan jumlah penduduk yang demikian besar, maka tidak mengherankan bila setiap negara menganggap orang Indonesia sebagai pasar yang sangat potensial dan sangat menjanjikan. Maka perusahaan-perusahaan sebagai penjual barang dan jasa baik perusahaan nasional maupun perusahaan multinasional, berlombalomba untuk masuk ke Indonesia dan menguasai pasar yang potensial tersebut. Dari sudut pandang Pemerintah, di satu sisi masyarakat dalam memilih semua kebutuhan yang 
diperlukan harus diberikan pendidikan dan pengetahuan agar jangan sampai memilih, membeli dan mengkonsumsi produk barang atau produk jasa yang salah atau tidak baik. Apabila penduduk membeli, memakai, dan mengkonsumsi produk yang berbahaya maka Pemerintah juga yang rugi, karena selain memerlukan biaya penyembuhanyangbesar juga dianggap tidak mampu melindungi warganya Dengan demikian maka penduduk sebagai pembeli, pemakai, dan pengguna barang dan atau jasa harus dilindungi dari akibat memilih dan membeli produk yang salah. Namun di sisi lain, para pengusaha juga harus mempelajari dan memahami tentang berbagai kebutuhan dan keperluan yang dinginkan oleh penduduk. Jangan sampai pengusaha yang telah membuat dan menawarkan produknya tidak laku di pasar karena tidak sesuai dengan kebutuhan dan keinginan penduduk sebagai pembeli. Maka dengan demikian diperlukan pengetahuan dan pemahaman tentang konsumen dan perilaku konsumen dalam memilih, membeli dan mengkonsumsi produk baik barang maupun jasa. (Suharsono, 2013 : 24)

Konsumen pada dasarnya dikelompokkan ke dalam dua kategori, yakni kategori pertama adalah konsumen individu, atau konsumen perseorangan atau konsumen perorangan. Seorang anak sekolah yang membeli sebuah buku di sebuah toko disebut sebagai konsumen individu atau konsumen perorangan. Seorang ibu yang sedang berbelanja di pasar, disebut sebagai konsumen individu atau konsumen perseorangan atau konsumen perorangan. Seorang mahasiswa yang sedang makan di sebuah kantin kampus, juga disebut sebagai konsumen individu. Seorang Dosen yang ketika berangkat ke sebuah kampus untuk mengajar, dan menggunakan kendaraan atau angkutan umum juga disebut sebagai konsumen individu. Demikian juga dengan seseorang yang sedang bepergian dengan menggunakan transportasi udara juga disebut sebagai konsumen individu. Dengan demikian, maka pengertian konsumen sangat mudah untuk dikenal dan dipahami. Karena sifatnya yang individu, maka jelas kiranya bahwa konsumen individu ini jumlahnya sangat besar. Maka tidak mengherankan, sesuai dengan uraian yang telah dibahas sebelum ini, dengan jumlah penduduk yang sangat besar, Indonesia merupakan pasar yang sangat 
potensial. Bagi seorang pelaku usaha konsumen individu yang jumlahnya besar ini lebih menjanjikan apabila mempunyai daya beli yang sangat kuat. (Suharsono, 2013 :26)

Konsep pemasaran adalah sebuah falsafah bisnis yang menyatakan bahwa pemuas kebutuhan konsumen merupakan syarat ekonomi dan sosial bagi kelangsungan hidup perusahaan

Faktor-faktor yang dipakai sebagai dasar dalam konsep pemasaran : orientasi pada konsumen.Orientasi pada konsumen berarti perusahaan selalu berusaha mengetahui kebutuhan pokok dari konsumen. Perusahaan yang benar-benar ingin memperhatikan konsumen harus :

- Menentukan kebutuhan pokok dari pembeli yang akan dilayani dan dipenuhi

- Memilih kelompok pembeli tertentu sebagai sasaran dalam penjualannya

- Menentukan produk dan program sasarannya

- Mengadakan penelitian pada konsumen untuk mengukur, menilai dan menafsirkan keinginan, sikap serta tingkah laku mereka.
- Menentukan dan melaksanakan strategi yangpalingbaik, apakah menitikberatkan pada mutu yang tinggi, harga yang murah, atau model yang menarik.

$\mathrm{K}$ o dan Integritas dalam PerusahaanPengintegrasian kegiatan pemasaran berarti bahwa setiap orang dari setiap barang dalam perusahaan turut berkecimpung dalam suatu usaha yang terkoordinir untuk memberikan kepuasan konsumen, sehingga tujuan perusahaan dapat terealisasi. Selain itu harus terdapat juga penyesuaian dan kondisi antara produk, harga, saluran distribusi, dan promosi untuk menciptakan hubungan pertukaran yang kuat dengan konsumen.

Mendapatkan Laba Melalui Pemuasan. Konsumen Salah satu tujuan dari semua perusahaan pada umumnya adalah mengoptimumkan laba atau orientasi laba, (profit orientation). Dengan laba ini perusahaan dapat tumbuh dan berkembang, dapat menggunakan kemampuan yang lebih besar, dapat memberikan tingkat kepuasan yang lebih besar pada konsumen, serta dapat memperkuat kondisi perekonomian secara keseluruhan. 
Pemasaran dan Peranan Pemerintah, Menurut WY. Stanton Pemasaran adalah sesuatu yang meliputi seluruh sistem yang berhubungan dengan tujuan untuk merencanakan dan menentukan harga sampai dengan mempromosikan dan mendistribusikan barang dan jasa yang bisa memuaskan kebutuhan pembeli aktual maupun potensial.

Pemasaran merupakan suatu kegiatan penyaluran barang atau jasa dari tangan produsen ke tangan konsumen.

Pemasaran sesuatu yang meliputi semua langkah yang dipakai atau dibutuhkan untuk menempatkan barang yang bersifat tangible ke tangan konsumen.

Menurut

Asosiasi Pemasaran Amerika Serikat / American Merketing Association Pemasaran adalah pelaksanaan kegiatan usaha pedagangan yang diarahkan pada aliran barang dan jasa dari produsen ke konsumen. Marketing atau Pemasaran adalah suatu perpaduan dari aktivitas-aktivitas yang saling berhubungan untuk mengetahui kebutuhan konsumen serta mengembangkan promosi, distribusi, pelayanan dan harga agar kebutuhan konsumen dapat terpuaskan dengan baik pada tingkat keuntungan tertentu. Dengan adanya pemasaran, konsumen tidak perlu lagi memenuhi kebutuhan pribadi secara sendiri-sendiri dengan melakukan pertukaran antara konsumen dengan pelaku pemasaran sehingga akan ada banyak waktu konsumen untuk kegiatan yang dikuasai atau disukai.

\section{Menurut}

Kotler

Pemasaran adalah suatu proses social dan manajerial yang membuat individu dan kelompok memperoleh apa yang mereka butuhkan dan inginkan lewat penciptaan dan pertukaran timbal balik produk dan nilai dengan orang lain. Pemasaran adalah bagaimana merayu agar prospek tahu, tertarik dan membeli produk/jasa kita sesring dan sebanyak mungkin dan merekomendasikannya kepada prospek lain.

$$
\text { Pemasaran adalah }
$$

selalu berusaha mengetahui apa yang konsumen inginkan (dan butuhkan), kemudian membuat produk dan mempersuasi sesuai dengan keinginan dan kebutuhan konsumen produk tersebut, untuk membuat konsumen tertarik dan membeli produk kita. mengemukakan definisi konsep pemasaran sebagai fungsi organisasi dan seperangkat proses untuk 
kreasi, komunikasi dan penyampaian nilai kepada para pelanggan dan mengelola hubungan pelanggan yang memberikan manfaat bagi organisasi dan para pemangku kepentingan (stakeholders) yang memiliki hubungan erat dengan organisasi. (George E. Belch, 2007 : 8)

\section{Pemasaran}

adalah

semua kegiatan yang bertujuan untuk memperlancar arus barang dan jasa dari produsen ke konsumen. Dalam pemasaran sebaiknya tidak terlalu ekstrem seperti pandangan barat, Islam adalah agama yang dianut oleh orang-orang yang ekstrem, karena yang dikenal oleh orang nonmuslim di Barat, teroris, pembunuh, pembajakan, pada umumnya dilakukan oleh orang Islam. Orang Barat menganggap bahwa terorisme sangat kental dalam peradaban Islam. Padahal dalam ajaran Islam, terorismeini dilarang. Islam wajib memelihara dan menjaga keamanan dan ketentraman bumi dan seisinya. Namun orang Barat tidak paham secara keseluruhan tentang ajaran Islam, sehingga menganggap Islam identik dengan terorisme. ( Ismail, 2016:1)

Kebijakan pemerintah dan intervensi harus menangani lebih dari tujuan perdagangan "rasionalisasi", yang sering terjadi dalam upaya untuk membuat praktik pemasaran sesuai mekanik ke model modern. Pemasaran intervensi harus mempertimbangkan kemampuan terbukti dari jaringan pemasaran. Kebijakan harus ditujukan untuk bekerja dengan sistem yang ada, bukan menggantikannya. Pemerintah mencoba untuk menggantikan sistem pasar bebas sering menaikkan biaya pemasaran, dengan demikian menyakiti konsumen, distorsi alokasi sumber daya dan merusak perekonomian. Adalah penting bahwa para pembuat kebijakan melihat perdagangan sebagai aktivitas yang diperlukan dan diinginkan sosial dilakukan dalam lingkungan risiko. Barang akan bisa laku apabila proses yang ada dalam perdagangan lancar karena kalau tidak ada yang melaksanakan perdagangan barang yang dibuat maka akan tidaklakuyangakhirnya proses produksi berhenti bahkan barang kurang begitu baik tapi kalau perdagangannya lancar akan semakin bisa laku.

Studi sistem pemasaran ternak di Afrika, pada kenyataannya, menunjukkan bahwa pasar sering tampil baik ketika dibiarkan pengusaha swasta. Hal ini umumnya 
direkomendasikan bahwa pemerintah memainkan memfasilitasi daripada peran langsung di pasar. Intervensi regulasi harus dibatasi. Intervensi yang tepat sehingga tidak langsung di alam dan memiliki tiga tujuan umum: untuk memperbaiki infrastruktur pasar, untuk meningkatkan informasi kelembagaan, untuk memperbaiki infrastruktur kelembagaan

Perluasan usaha yang secara sepintas memiliki pasar potensial cukup besar namun setelah pelaksanaannya pasar potensial tersebut tidak cukup tersedia dan timbul dikemudian hariyang cukup rumit untuk diselesaikan. (Suad, 1997 : 31) Sedangkan untuk macam-macam pasar yaitu ada pasar konsumen yaitu pasar untuk barang dan jasa yang dibeli oleh perorangan,pasar industri yaitu yaitu pasar untuk barang dan jasa yang dibeli untuk digunakan memproduksi barang atau jasa, baik untuk dijual atau dipakai lebih lanjut, pasar pemerintah yaitu terdiri dari unit-unit pemerintah untuk menjalankan tugastugas pemerintahan misalnya (pendidikan, perhubungan dan kesehatan).

\section{B. Persepsi}

Persepsi merupakan proses akal manusia yang sadar yang meliputi proses fisik, fisiologis, dan psikologi yang menyebabkan berbagai macam input, lalu diolah menjadi suatu penggambaran lingkungan.

Persepsi merupakan perlakuan yang melibatkan penafsiran melalui proses pemikiran tentang apa yang dilihat, dengar, alami atau dibaca, sehingga persepsi bisa mempengaruhi tingkah laku, percakapan, serta perasaan seseorang.

Untuk memberikan gambaran lebih jelas lagi mengenai persepsi, berikut pengertian yang dikemukakan oleh beberapa ahli. Persepsi adalah kemampuan seorang untuk mengorganisir suatu pengamatan, kemampuan tersebut antara lain : kemampuan untuk membedakan, kemampuan untuk mengelompokkan, dan kemampuan untuk memfokuskan. (www. Jurnal Strategi, 2017) Oleh karena itu seseorang bisa saja memiliki persepsi yang berbeda, walaupn objeknya sama. Hal tersebut dimungkinkan karena adanya perbedaan dalam hal sistemnilaidancirikepribadian individu yang bersangkutan. Sedangkan menurut Leavit persepsi memiliki pengertian dalam arti sempit dan arti 
luas. Dalam arti sempit persepsi yaitu penglihatan: bagaimana seseorang melihat sesuatu, dan dalam arti luas persepsi yaitu: pandangan atau pengertian, bagaimana seseorang memandang atau mengartikan sesuatu. Kotler menjelaskan persepsi sebagai proses bagaimana seseorang menyeleksi, mengatur dan menginterpretasikan masukan-masukan informasi untuk menciptakan gambaran keseluruhan yang berarti. Mangkunegara berpendapat bahwa persepsi adalah suatu proses pemberian arti atau makna terhadap lingkungan. Dalam hal ini persepsi mecakup penafsiran obyek, penerimaan stimulus (Input), pengorganisasian stimulus, dan penafsiran terhadap stimulus yang telah diorganisasikan dengan cara mempengaruhi perilaku dan pembentukan sikap.

Persepsi juga dapat diartikan sebagai pengalaman tentang objek, peristiwa, atau hubungan yang diperoleh dengan menyimpulkan informasi dan menampilkan pesan. Setiap orang memiliki persepsi yang berbedabeda meskipun objeknya sama. Studi tentang persepsi sangat berkaitan dengan studi kognitif, seperti ingatan dan berfikir, disamping itu praktik dan pengalaman juga mempengaruhi persepsi. Persepsi diyakini sebagai proses dan hasil. Dua hal ini biasa dikenal dengan sebutan penghayatan dan pemahaman berturut-turut. Penghayatan didasarkan pada kondisi tertentu, merupakan proses kognitif, seperti ingatan, pernyataan berfikir Pada dasarnya persepsi merupakan pemahaman terhadap apa yang terjadi di lingkungan masyarakat.

Persepsi merupakan pengalaman tentang objek, peristiwa atau hubunganhubungan yang diperoleh dengan menyimpulkan informasi dengan menafsirkan pesan. Proses terbentuknya persepsi melalui tiga tahap, yaitu fisik, fisiologik, dan psikologik. Adanya objek menimbulkan stimulus lalu stimulus mengenai alat indra. Stimulus yang diterima alat indra, dilanjutkan oleh alat sensoris ke otak sehingga terjadi suatu proses di otak mengakibatkan individu dapat menyadari apa yang diterimanya. Proses ini disebut proses pengamatan. Setelah terjadi proses pengamatan, maka akan terbentuklah persepsi tentang objek.

Dalam Kamus Besar Bahasa Indonesia persepsi adalah proses seseorang mengetahui beberapa hal melalui panca inderanya. 
Sementara itu

Sarwono dalam konvensional dianggap sebagai kumpulan pengideraan, proses pengenalan objek yang merupakan aktivitas kognisi di mana otak aktif menggabungkan kumulasi (tumpukan) pengalaman dan ingatan masa lalu serta aktif menilai untuk memberi makna dan penilaian baik atau buruk. Persepsi dapat juga dinyatakan bahwa persepsi adalah pengamatan tentang objek peristiwa atau hubungan-hubungan yang diperoleh dengan menyimpulkan informasi dan menafsirkan pesan. Persepsi juga memberikan makna pada stimuli indera/sensor stimulan.

Dengan demikian dapat disimpulkan persepsi adalah proses pengenalan terhadap objek (benda, manusia, gagasan, gejala dan peristiwa) melalui panca indera sehingga dengan serta merta memberi makna dan nilai kepada suatu objek dengan menonjolkan sifat khas dari suatu obyek serta hasil dari persepsi bisa bisa berupa tanggapan atau penilaian yang berbeda dari individu. Persepsi sosial meliputi empat tahap proses informasi, yaitu tahap pertama adalah perhatian yang selektif dan pemahaman. Pada fase ini terjadi proses untuk menyadari sesuatu atau orang, tahap kedua adalah pengkodean dan penyederhanaan.Pada fase ini penerima pesan memberikan informasi-informasi dalam kategori kognitif. Kategori kognitif yaitu gambaran mental atas suatu peristiwa atau objek, tahap ketiga adalah penyimpanan. Pada fase ini penerima pesan memasukkan informasi ke dalam ingatan jangka panjang yang tersusun dalam tiga ruangan yaitu informasi tentang peristiwa khusus dan umum, semantik yaitu ruangan yang menunjukkan pada pengetahuan umum tentang dunia, individu yaitu ruangan yang berisikan tentang individu tunggal atau kelompok-kelompok organisasi, tahap keempat adalah tanggapan, penilaian dan keputusan. Pada fase ini keputusan didasarkan pada penafsiran dan perpaduan antara informasi kategori yang disimpan dalam ingatan jangka panjang.

Berdasarkan pendapat para ahli yang telah dikemukakan, bahwa proses persepsi melalui tiga tahap, yaitu: tahap penerimaan stimulus, baik stimulus fisik maupun stimulus sosial melalui alat indera manusia, yang dalam proses ini 
mencakup pula pengenalan dan pengumpulan informasi tentang stimulus yang ada, tahap pengolahan stimulus sosial melalui proses seleksi serta pengorganisasian informasi, tahap perubahan stimulus yang diterima individu dalam menanggapi lingkungan melalui proses kognisi yang dipengaruhi oleh pengalaman, cakrawala, serta pengetahuan individu.

Menurut Newcomb ada beberapa sifat yang menyertai proses persepsi, yaitukonstansi (menetap) di mana individu mempersepsikan seseorang sebagai orang itu sendiri walaupun perilaku yang ditampilkan berbeda-beda,

Selektif di mana persepsi dipengaruhi oleh keadaan psikologis si perseptor. Dalam arti bahwa banyaknya informasi dalam waktu yang bersamaan dan keterbatasan kemampuan perseptor dalam mengelola dan menyerap informasi tersebut, sehingga hanya informasi tertentu saja yang diterima dan diserap.

\section{Faktor-Faktor Yang Mempengaruhi Persepsi}

\section{Persepsi seseorang} tidak timbul begitu saja, tetapi ada faktor yang mempengaruhinya. Persepsi seseorang ada kaitannya dengan keputusan untuk bertindak. Ada 3 faktor yang mempengaruhi persepsi seseorang, yaitu: diri orang yang bersangkutan yaitu apabila seseorang melihat sesuatu dan berusaha memberikan interpretasi tentang apa yang dilihatnya, orang tersebut dipengaruhi oleh karakteristik individual yang turut berpengaruh seperti sikap, motif, kepentingan, minat, pengalaman, dan harapan, kedua sasaran persepsi tersebut yaitu sifatsifat sasaran itu biasanya berpengaruhterhadappersepsi orang yang melihatnya, ketiga faktor situasi yaitu situasi merupakan faktor yang turut berperan dalam penumbuhan persepsi seseorang.

Persepsi masyarakat tentang sehat dan sakit sangat dipengaruhi oleh pengalaman masa lalu, disamping unsur sosial dan budaya. Sebaliknya, petugas kesehatan sedapat mungkin menerapkan kriteria medis yang objektif berdasarkan simtom untuk mendiagnosa pasien. Masyarakat mulai menghubungi sarana kesehatan sesuai dengan pengalamannya atau dari informasi yang diperoleh dari orang lain karena disadari atas kepercayaan dan keyakinan akan kemajuan sarana kesehatan tersebut. 


\section{METODE PENELITIAN}

Dalam penelitian kali ini, penulis menggunakan jenis penelitian field Reseach (Penelitian lapangan) yaitu penelitian yang mengambil data primer dari lapangan atau lokasi penelitian tertentu. (Suharsini, 1993 : 202) Jadi dalam hal ini penelitian yang penulis lakukan berdasarkan pada data-data lapangan dan literatur yang berkaitan pada pokok persoalan yang dibahas.

Pendekatan penelitian kualitatif bertujuan untuk memahami (Understanding) duniamaknayang disimbolkan dalam perilaku masyarakat menurut perspektif masyarakat itu sendiri. Karena bersifat understanding, data penelitian kualitatif bersifat naturalistik, metodenya induktif, pelaporannya bersifat deskriptif dan naratif. Metode penelitian kualitatif disebut juga penelitian naturalistic karena penelitian dilakukan pada kondisi alamiah, disebut juga sebagai metode etnografi, karena pada awalnya metode ini lebih banyak digunakan di penelitian bidang budaya, disebut sebagai metode kualitatif, karena data yang terkumpul dan analisisnya lebih bersifat kualitatif. (Sugiono, 2005 : 2005)

Penelitian ini dilakukan pada daerah-daerah di mana daerah tersebut ada beberapa orang yang menjadi anggota suatu BMT baik mereka yang berwirausaha maupun yang berdagang yang berguna bisa untuk memajukan semua usaha yang mereka tekuni.

Dalam penelitian ini, peneliti bertindak sebagai pengumpul data dan sebagai instrumen aktif dalam upaya mengumpulkan data-data di lapangan. Sedangkan instrumen pengumpulan data yang lain selain manusia adalah berbagai bentuk alat-alat bantu dan berupa dokumen-dokumen lainnya yang dapat digunakan untuk menunjang keabsahan hasil penelitian, namun berfungsi sebagai instrumen pendukung. Kehadiran dan keterlibatan peneliti untuk menemukan makna dan tafsiran tidak dapat digantikan oleh alat lain, sebab hanya peneliti yang dapat mengkonfirmasikan dan mengadakan pengecekan. Selain itu, melalui keterlibatan langsung di lapangan dan diketahui adanya informasi tambahan dari informan berdasarkan cara pandang, pengalaman, keahlian dan kedudukannya. Ada beberapa hal yang harus dimiliki peneliti sebagai instrumen yaitu responsif, dapat menyesuaikan diri, menekankan keutuhan mendasarkan diri atas 
perluasan

pengetahuan, memproses data secepatnya serta

kesempatan

mengklarifikasi

mengikhtisarkan.

Kehadiran peneliti di

lokasi penelitian ada 4 tahap yaitu apprehension, exploration, cooperation dan participation. Peneliti harus berusaha dapat menghindari pengaruh subyektif dan menjaga lingkungan secara alamiah agar proses sosial yang terjadi sebagaimana biasanya. Peneliti berusaha sebaik mungkin bersikap selektif, penuh kehati-hatian, dan serius dalam menyaring data sesuai dengan realitas di lapangan sehingga data yang terkumpul benar-benar relevan dan terjamin keabsahannya. Peneliti sebisa mungkin menghindari kesan-kesan yang dapat menyinggung perasaan maupun merugikan informan.

ilmiah metiap penelitian dalam memecahkan masalah yang dihadapinya. Data harus diperoleh dari sumber data yang valid, agar data yang terkumpul relevan dengan masalah yang diteliti, sehingga tidak menimbulkan kekeliruan dalam penyusunan interprestasi dan kesimpulan. Untuk memperoleh data yang bersifat akurat, mula- mula yang dilakukan dalam penelitian terhadap data sekunder, yang kemudian dilanjutkan dengan penelitian lapangan untuk memperoleh data primer.

Penelitian

ini

menggunkan

wawancara tak berstruktur yaitu wawancara yang bebas di mana peneliti tidak menggunakan pedoman wawancara yang telah tersusun secara sitematis dan lengkap untuk pengumpulan datanya. Pedoman dalam wawancara tak terstruktur yang digunakan hanya berupa garis-garis besar permasalahan yang akan ditanyakan. Dalam wawancara tidak tersruktur peneliti belum mengetahui secara pasti data apa yang akan diperoleh, sehingga peneliti lebih banyak mendengarkan apa yang diceritakan oleh responden.

Adapun analisis yang digunakan adalah Analisis deskriptif yaitu metode yang bertujuan untuk melihat sejauh mana variabel yang diteliti telah sesuai dengan tolak ukur yang telah ditetapkan. Analisis ini digunakan untuk mendeskripsikan hasil penelitian data dari variabel yang diteliti. Dalam analisis ini peneliti akan mendiskripsikan mengenai studi kelayakan pembiayaan.

Untukmenganalisa data 
yang telah diperoleh melalui wawancara observasi dan dokumentasi, maka peneliti melakukan analisis melalui pemaknaan atau proses interpretasi terhadap datadata yang telah diperolehnya. Analisa yang dimaksud merupakan upaya mencari dan menata secara sistematis catatan hasil observasi, wawancara dan dokumentasi untuk meningkatkan pemahaman peneliti tentang persoalan yang diteliti dan menyajikan sebagai temuan bagi orang lain. Dalam penelitian ini, metode yang digunakan adalah metode analisis data menurut Miles \& Huberman yaitu analisis model interaktif. Analisis data berlangsung secara simultan yang dilakukan bersamaan dengan proses pengumpulan data dengan alur tahapan: pengumpulan data (data collection), reduksi data (data reduction), penyajian data (data display) dan kesimpulan atau verifikasi (conclution drawing $\mathcal{E}$ verifying).

\section{HASIL} PEMBAHASAN

A. Pemasaran yang dilakukan oleh para anggota BMT

Sebelum mengerjakan suatu bisnis, hendaknya analisis terhadap pasar potensial yang akan dimasuki oleh produk yang akan dihasilkan oleh perusahaan dilakukan terlebih dahulu. Dengan demikian akan diketahui keberadaan pasar potensial yang dimaksud. Atau, bisnis akan mencoba menciptakan potensialnya sendiri sehingga produk dapat menjadi leader. Atau, oleh karena hasil analisis menyatakan bahwa produk dan bisnis yang akan ditawarkan akan sulit diterima oleb pasar potensialnya, maka rencana bisnis akan dianggap tidak layak. Keseluruhan analisis ini hendaknya dilakukan dalam salah satu aspek aspek Pasar. Pasar, menurut para ahli, merupakan tempat pertemuan antara penjual dan pembeli, atau sating bertemunya antara kekuatan permintaan dan penawaran untuk membentuk suatu harga. Pendapat ahli yang lain mengatakan bahwa pasar merupakan suatu sèkelompok orang yang diorganisasikan untuk melakukan tawar-rnenawar, sehingga dengan demikian terbentuk harga.

Permintaan

Penawaran.

dan

permintaan

menghasilkan

Analisis permintaan terhadap suatu produk merupakan salah satu alat penting bagi manajemen perusahaan. Dari prakiraan 
penjualan, perusahaan dapat memprakirakan anggaran perusahaan, dan dari anggaran perusahaan dapat ditentukan, misalnya jumlah dan macam tenaga kerja yang dibutuhkan, kecukupan alat-alat produksi, ketersediaan bahan mentah dan daya tampung gudang. Permintaan dapat diartikan sebagai jumlah barang yang dibutuhkan konsumen yang mempunyai kemampuan untuk membeli pada berbagai tingkat harga. Permintaan yang didukung oleh kekuatan tenaga beli disebut permintaan efektif, sedangkan permintaan yang didasarkan pada kebutuhan saja disebut sebagai permintaan potensial. Hukum permintaan mengatakan bahwa bila harga suatu barang meningkat, maka kuantitas barang yang diminta akan berkurang, begitu pula sebaliknya, bila harga barang yang diminta menurun, maka kuantitas barang yang diminta akan naik (asumsi ceteris paribus).

Di sisi lain, penawaran diartikan sebagai berbagai kuantitas barang yang ditawarkan di pasar pada berbagai tingkat harga. Dalam fungsi ini, bila harga suatu barang meningkat, maka produsen akan berusaha meningkatkan jumlah barang yangdijualnya.Sampaidimana penjual ingin menawarkan barangnya pada berbagai tingkat harga ditentukan oleh berbagai faktor, di antaranya ialah: harga barang itu sendiri, harga barang lain, ongkos produksi, tingkat teknologi, dan tujuan-tujuan perusahaan. Konsep permintaan di dalam pasar terbagi menjadi dua bagian, yaitu permintaan konsumen dan permintaan pasar. Permintaan konsumen (secara terhadap barang dan jasa akan menentukan macam serta jumlah barang dan jasa yang harus dihasilkan, berapa biaya yang diperlukan serta berapa harga barang tersebut.

Permintaan perseorangan tidak akan mampu mempengaruhi harga dan persediaan barang, akan tetapi jika bersama-sama akan membentuk sisi permintaan dalam pasar. Dalam analisis, perlu dicari fungsi permintaan yang menunjukkan hubungan antara jumlah barang yang dimintadengansemuavariabe1 yang mempengaruhinya untuk dapat dipakai dalam pengambilan keputusan manajemen.

Selain Marketing Mix fasilitas juga dapat membuat suatu keadaan yang nyaman baik bagi diri sendiri juga bagi lingkungan sekitar. Rasa tidak nyaman misalnya rasa gelisah karena merasatidakada tempat untuk beristirahat akhirnya 
berpengaruh terhadap segala macam bentuk kegiatan yang akan dilakukan. Fasilitas dapat diartikan sebagai yaitu segala sesuatu yang disediakan guna untuk dapat dipakai maupun dipergunakan sehingga orang akan merasa nyaman dan mudah dalam penggunaan di mana dalam pengggunaan tersebut yang memakai gratis tidak membayar karena sudah masuk dalam harga yang telah dibuat atau hanya untuk supaya orang lebih nyaman yang tujuannya agar penjualan lebih banyak. Peningkatan dapat diperoleh dengan memperbanyak fasilitas yang ada misalnya tempat parkir yang mudah dan lebih baik kalau gratis, kursi untuk tempat duduk yang nyaman untuk digunakan tetapi kalau bisa tempat duduknya jangan terlalu panjang karena kalau panjang maka akhirnya digunakan untuk tidur yang sangat menggangu orang lain dan dalam menjual juga disediakan tas atau apa saja yang bisa dipakai untuk membawa pada saat berbelanja di dalam ruangan. Fasilitas memang secara teori sangat mendukung suatu penjualan tetapi ada beberapa yang kurang begitu pengaruh. Hal ini bisa kita lihat pada retoranrestoran yang kelihatan mewah tetapi kadang malah penjualannya tidak begitu laku tetapi ada beberapa warung yang kelihatan sederhana tetapi penjualan malah laku.

Pemasaran juga bisa memakai suatu warna yang cocok dengan usaha yang telah dijalankan misalnya saja yang paling mudah adalah dalam membuat air minum kemasan maka sebaiknya memakai botol yang bening warna tulisan biru karena orang akan melihat lebih jernih dan segar. Lokasi merupakan salah satu faktor penting yang perlu diperhatikan pada usaha pasar. Lokasi lokasi yang baik setidaknya harus dekat dengan pusat, jarang bahkan tidak pernah terjadi banjir atau sangat bebas banjir, dan dekat dengan perkotaan atau aksesnya mudah. Lokasi usaha yang strategis yang dapat dicapai dengan mudah akan memudahkan konsumen untuk mengambil keputusan pembelian. Salah satu kunci menuju sukses dalam dunia usaha adalah lokasi. Lokasi dimulai dengan memilih komunitas yang akan menjadi calon konsumen utama produk atau jasa yang ditawarkan.

\section{B. Strategi pemasaran untuk meningkatkan usaha para anggota BMT}

Strategi yang ada dalam suatu pemasaran meliputi 
analisis SWOT. Strengths yaitu kekuatan, weaknesses artinya kelemahan, opportunities artinya peluang dan threats artinya ancaman. Kekuatan yang ada dalam pemasaran harus dipertahankan misalnya sudah punya nama yang baik dan sudah tahu bagaimana cara meraih konsumen maka harus dipertahankan dengan cara cara yang dilakukan harus dipertahankan jangan sampai dikurangi dan banyak sekali kalau sudah langganan akan dikurangi fasilitasnya seharusnya mempertahankan konsumen adalah lebih sulit daripada mencari pelanggan baru. Kalau ada konsumen yang pernah beli atau menggunakan jasa kemudian dia menggunakan lagi maka dipastikan barang atau jasa cenderung diminati. Weakness adalah mempunyai arti kelemahan yang ada adalah lemah dalam pengendalian keuangan yang dilakukan oleh beberapa usaha misalnya masalah keuangan di mana jarang melakukan pencatatan walaupun dalam pembuatan nota sudah ditulis tetapi masih hanya sebagai nota untuk pengambilan barang tidak dipakai untuk menghitung berapa pemasukan yang ada dan pengeluaran yang telah dikeluarkan dan ini merupakan kelemahan pada usaha.

\section{PENUTUP}

Kemampuan lembaga keuangan dalam menciptakan dana untuk mengembalikan pembiayaan

sangat

dipengaruhi oleh keberhasilan pemasaran dari para anggota atau dari nasabah suatu lembaga keuangan. Semakin maju dan berhasil pemasaran hasil produksi, akan semakin besar kemampuan perusahaan meningkatkan jumlah penjualan dan keuntungan yang akhirnya bisa membayar kepada lembaga keuangan. Pemasaran baik jasa maupun produk harus berpatokan baik secara internal maupun secara external. Secara internal lewat Marketing Mix yaitu produk, harga, distribusi dan promosi sedangkan kalaulewatexternal meliputi

perkembangan kehidupan ekonomi umum, perkembangan keadaan politik Negara, perkembangan suasana persaingan pasar, peraturan atau keputusan pemerintah. Dengan pelaaksanaan yang baik atau BMT menggunakan Marketing Mix akan dapat meningkatkan usaha para anggota lembaga keuangan syariah salah satunya adalah BMT. Misalnya lembaga keuangan syariah membuat suatu produk yang dibutuhkan oleh masyarakat maka masyarakat akan menggunakan produk 
tersebut tersebut yang untuk mendapatkan hadiah. akhirnya para anggota bisa Perbankankonvensionalsudah berusaha yang ujungnya ada melaksanakan promosi secara peningkatan ekonomi. Harga terus menerus misalnya lewat juga akan bisa memajukan atau meningkatkan penjualan akan suatu produk maka sebaiknya setelah bisa membuat suatu produk maka langkah selanjutnya adalah membuat harga atau bagaimana tingkat bagi hasil yang akan disepakati dalam lembaga keuangan syariah tersebut. Promosi juga harus dilakukan setelah sudah ada harga yang akan ditentukan, promosi bisa berupa pemberian bonus baik bagi para karyawan maupun bagi para anggota yang diperkirakan layak event-event tertentu maupun pemberian hadiah kepada para nasabah terutama nasabah yang mempunyai tabungan. Distribusi yang dilakukan oleh lembaga keuangan harusnya juga merata artinya mempunyai cabang yang banyak dan juga orang yang mendapatkan pendanaan juga merata tidak hanya pada kelompok-kelompok tertentu atau bahkan orang yang punya agunan saja yang mendapatkan pendanaan. 


\section{REFERENSI}

George E. Belch dan Michael A. Belch, Advertising \& Promotion: an IMC Perspective, 2007.

$\mathrm{h} \mathrm{t} \mathrm{t} \mathrm{p}: / / \mathrm{i} \mathrm{d}, \mathrm{p}$ o $\mathrm{r}$ t a 1 g a r u d a. org $/$ ? ref=browse\&mod=viewarticle\&article $=193602$ diakses pada 27 April 2017) jurnal Strategi pemasaran.

(http://journal.uny.ac.id/index.php/jpakun/article/view/835diakses pada tanggal 25 April 2017).

Ismail, Perbankan Syariah, Perpustakaan Nasional catalog dalam terbitan , 2016.

Jusuf Soewadji, MA, Pengantar Metodologi Penelitian, Jakarta: Mitra Wacana Media, 2012.

Lexy J, moelong, metodologi Penelitian Kualitatif, Bandung: PT. Remaja Rosdakarya, 2007.

Mulyadi Nitisusastro,Perilaku Konsumen, Alfabeta, 2013.

Mudrajad Kuncoro, Strategi Bagaimana Meraih Keunggulan Kompetitif, Erlangga, Jakarta,2005.

Nazir, Metode Penelitian, Ghalia Indonesia, Jakarta, 1998.

Suad Husnan, Studi Kelayakan Proyek, AMP YKPN, Yogyakarta, 1997.

Suharsini Arikunto, Prosedur Penelitian Suatu Pendekatan Praktik, Rineka Cipta, Jakarta, 1993.

Sukardi, Metodologi Penelitian Pendidikan Kompetensi dan Praktiknya, Jakarta: Bumi Aksara,2005.

Sugiyono, Metode Penelitian Pendidikan Pendekatan Kuantitatif, Kualitatif, R E D, Alfabeta, Bandung, 2006. 
Sugiono, Metode Penelitian Kuantitatif \& Kualitatif, Alfabeta, Bandung, 2013.

Suharsono, Komunikasi Bisnis, CAPS, Yogyakarta, 2013. 